\title{
Retraction Note: The specific MYB binding sites bound by TaMYB in the GAPCp2/3 promoters are involved in the drought stress response in wheat
}

\author{
Lin Zhang, Zhiqiang Song, Fangfang Li, Xixi Li, Haikun Ji and Shushen Yang*
}

\section{Retraction note to: BMC Plant Biol 19, 366 (2019) https://doi.org/10.1186/s12870-019-1948-y}

The editor of BMC Plant Biology has retracted this article [1] due to concerns about the figures. Specifically, it was brought to the attention of the journal that:

- The TaGAPCp3/TaMyb panel of Fig. 6B is similar to TaGAPCp2P-1/TaMyb panel of Fig. 9B in the same article and Fig. 5D of a different publication by the some of the same authors [2];

- TaGAPCp3P-3/TaMyb of Fig. 9B appears to overlap with the TaGAPC1P-3/TaWRKY40 panel in Fig. 6C of another paper by some of the same authors [3];

- Fig. 5A (OE-2 and OE-3; drought 25d) appears to overlap with Fig. 2A (OE; drought 25d) of another article [3]

Due to the problematic figures, the editor considers the data presented to be unreliable.

All authors agree to this retraction and apologize to the readers for any inconvenience caused.

Published online: 21 December 2020

\section{References}

1. Zhang L, Song Z, Li F, et al. The specific MYB binding sites bound by Ta_

MYB in the_GAPCP2/3 promoters are involved in the drought stress

The original article can be found online at https://doi.org/10.1186/s12870019-1948-y.

* Correspondence: yangshushen2014@163.com

College of Life Sciences, Northwest A\&F University, Yangling 712100, Shaanxi, China

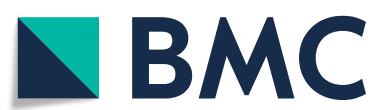

C C The Author(s). 2020 Open Access This article is licensed under a Creative Commons Attribution 4.0 International License, which permits use, sharing, adaptation, distribution and reproduction in any medium or format, as long as you give appropriate credit to the original author(s) and the source, provide a link to the Creative Commons licence, and indicate if changes were made. The images or other third party material in this article are included in the article's Creative Commons licence, unless indicated otherwise in a credit line to the material. If material is not included in the article's Creative Commons licence and your intended use is not permitted by statutory regulation or exceeds the permitted use, you will need to obtain permission directly from the copyright holder. To view a copy of this licence, visit http://creativecommons.org/licenses/by/4.0/ The Creative Commons Public Domain Dedication waiver (http://creativecommons.org/publicdomain/zero/1.0/) applies to the data made available in this article, unless otherwise stated in a credit line to the data. 